\title{
ECHOES SWCS Annual Conference reflections
}

\author{
Jim Gulliford
}

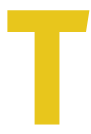
his year's 66th International Annual Conference of the Soil and Water Conservation Society brought more than 500 conservationists to Washington, DC. For the 40 international participants from 15 countries and for conference participants from throughout the United States, it was an opportunity to visit the United States' capital city and examine global perspectives of conservation science and policy.

The plenary sessions concentrated on global efforts to address food security and agricultural land sustainability. The Fellows Forum featured a report from Mike Gangwer of the Foreign Agricultural Service on US efforts to assist postwar Afghanistan and Iraq in the restoration of agricultural infrastructure and production.

Former USDA Agriculture Secretary Dan Glickman (1995-2001) delivered the $\mathrm{H}$. Wayne Pritchard Lecture. He shared experiences from his service as Agriculture Secretary and also his current global agricultural development initiatives as cochair of the Chicago Council on Global Affairs. A video of the Pritchard Lecture is available on the SWCS Web site. If you were not able to attend the 2011 conference, the video is a "must see."

Jorge Delgado, USDA Agricultural Research Service Soil Scientist at Fort Collins, Colorado, presented the Society's science assessment of how soil and water conservation practices can contribute to the mitigation of and adaptation to climate change. The article "Conservation practices to mitigate and adapt to climate change" was published in the July/August 2011 issue of the Journal of Soil and Water Conservation. The video of Jorge Delgado's presentation is available on the SWCS Web site at http://www.swcs.org.

Andy Manale, Chair of the SWCS Science and Policy Committee, presented the Society's position statement on climate change adopted by the Society's Board of

Jim Gulliford is executive director of the Soil and Water Conservation Society.
Directors on July 7, 2011. It establishes the position of the Society with respect to climate change and agriculture and articulates principles of soil and water conservation research, practice, and outreach to mitigate and adapt to climate change. The official document titled "Position Statement on Climate Change and Soil and Water Conservation" is available on the SWCS Web site at http://www.swcs. org/climate.

On Wednesday, the Society and the Farm Foundation hosted a Farm Bill Forum that featured perspectives of the congressional agriculture committees on the history and conservation objectives of the current and former conservation titles. Two panels of speakers presented policy perspectives, financial issues, and institutional priorities that will be central to the next Farm Bill. Both panels were thought provoking and led to excellent discussion by forum participants.

This year's symposia, concurrent sessions, and posters were selected from the largest pool of submissions that the Program Committee and Chair Rebecca Power have ever received. The effort of each author and symposium organizer created an exciting set of educational and networking options for conference participants to choose from.

One of the most enjoyable aspects of each Annual Conference is the awards luncheon, which honors outstanding individuals and chapters for acts of achievement or career contributions to the Society and soil and water conservation. This year, Andrew Sharpley, Professor at the University of Arkansas-Fayetteville, received the Hugh Hammond Bennett Award for his career research addressing phosphorus in soil, the fate and mechanisms of loss in runoff, and the challenge of phosphorus as a national water quality issue. Robin Foulk of USDA Natural Resources Conservation Service, Doug Karlen of USDA Agricultural Research Service, and Larry Wright of USDA Natural Resources Conservation Service were designated Fellows of the Society for

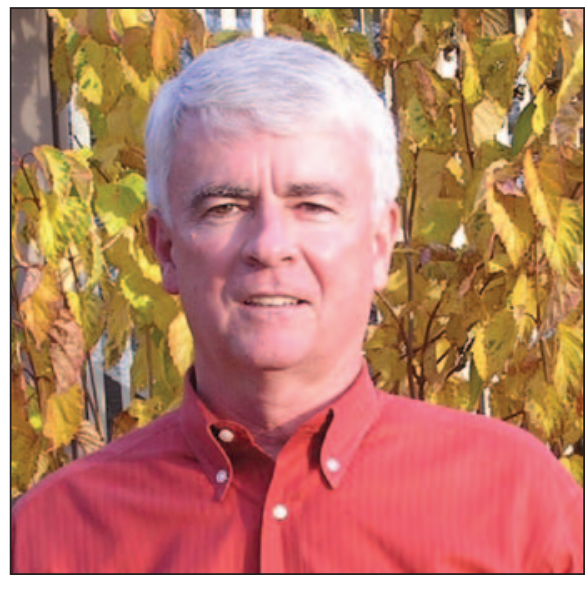

Jim Gulliford

their career contributions to the Society and soil and water conservation. The entire list of 2011 awardees can be found on the SWCS Web site.

We also want to recognize and express our appreciation for the financial support of our conference sponsors: Pioneer Hi-Bred, A DuPont Business; the Sand County Foundation; Cargill; and the National Capital Chapter. Many thanks also to the companies, agencies, and organizations who participated in the conference trade show.

Finally, this conference could not have been the success if it was without the efforts of many Society members and local volunteers. The National Capital Chapter and Rebekah DeWind, Chair of the Local Arrangements Committee, provided leadership for the volunteers who moderated sessions, led tours, and supported the audio and video for the educational sessions. Committee chairs, SWCS staff, and your Board of Directors were instrumental in the development and operation of the conference.

History, science, policy, and global perspectives were each a part of this year's Annual Conference. For each participant, the conference provided opportunities for leadership, training, presentation, education, and networking. We hope each participant left the conference excited about the opportunity to continue the important work of soil and water conservation. 